\title{
Effect of Labour Saving Technology on Crop Productivity in Northern Dry Zone of Karnataka
}

\author{
Gunabhagya $^{1^{*}}$ and Amrutha T. Joshi ${ }^{2}$ \\ ${ }^{1}$ ZBNF Project (Zone-3) College of Agriculture, VIjayapur (UASD) Karnataka, India \\ ${ }^{2}$ Agricultural Economics, College of Agriculture, Raichur, Karnataka, India \\ *Corresponding author
}

\begin{abstract}
A B S T R A C T
\section{Keywords}

Labour Saving

Technology,

Adopters and non adopters

\section{Article Info}

Accepted:

22 June 2020

Available Online:

10 July 2020

Today agriculture labour has become the most important component in Indian agriculture. The proportion of agricultural workers to the total workers has been declining over the years, while the corresponding ratio in the secondary and tertiary sectors is on the rise. Pursuant to this, following impacts have been predominantly noticed in agriculture in recent years: reduction in crop yield, reduction in cropping intensity and changes in traditional cropping pattern. Scarcity of farm labourers is a grave concern for the farmers, who may not even hesitate to abandon farming. It was revealed from the study that, the productivity difference was more pronounced in paddy $(850 \mathrm{~kg} / \mathrm{ha})$, followed by cotton $(319 \mathrm{~kg} / \mathrm{ha})$ and $(224 \mathrm{~kg} / \mathrm{ha})$. Further, reduction in yield the selected crops in labour scarcity affected farms, in comparison with unaffected farms. The productivity difference was more pronounced in cotton crop (16.43\%), paddy (13.04) and in case of redgram it was $(3.84 \%)$. In order to overcome the labour scarcity custom hiring is to be encouraged among farmers for adoption of the highly expensive labour saving technologies and implements.
\end{abstract}

\section{Introduction}

Even though India has the second largest man power in the world, all sectors of the economy have been affected by the scarcity of labour, and the impact being felt more in the agricultural sector. Labourers constitute a vital input in agricultural production, but they are migrating to different parts of the country for earning a better livelihood, adding to the existing imbalance between labour demand and supply of labourers (Deshingkar and Start 2003).
The phenomenon of underemployment is manifested in daily lives as a large proportion of labour demand is met by wage labour, due to the skewed land distribution and seasonality of demand in agriculture. They usually get low wages, undertake laborious jobs and have highly irregular employment (Padhi, 2007). Agricultural labourers are at severe risk of poverty that permits routes out of agricultural labour, particularly across generations; however, agricultural labourers are not generally well placed to take advantage of them and mobility out of 
agricultural labour remains low (Dreze et al., 1992).

Agriculture labour is a person who is hired by an employer for involving in the science, art and business of cultivating land including the gathering of crops, and rearing of live-stock i.e. farming; husbandry which is used to sustain life. In 1961 census, those agricultural workers were taken as agricultural labourers whose main source of income was wage earning, and in 1971 census, the emphasis was on main activity i.e., whose main activity was to work on another person's field for payment.

The proportion of agricultural workers to the total workers has been declining over the years, while the corresponding ratio in the secondary and tertiary sectors is on the rise. Pursuant to this, following impacts have been predominantly noticed in agriculture in recent years: reduction in crop yield, reduction in cropping intensity and changes in traditional cropping pattern. Though agricultural research has evolved-in many crop specific, labour-saving implements and technologies, the problem has not been addressed fully. Another matter of concern is that in the sociological perspective, the vocation of casual agricultural labour is considered to be the last resort and hence preferred only by people who have no other means of livelihood (Prabakar et al., 2011).

There is an acute shortage of labour in every sector in India. However, in the name of welfare measures, Government of India and the state Governments are taking away a lot of people from workforce, thereby enhancing shortage of labour and curtailing growth in GDP. In India, particularly in the southern states, there is an acute shortage of skilled and unskilled manpower in every sector of the economy. Labourers constitute a vital input in agricultural production, but they are migrating from one place to another, implementation of MGNREGA program during peak agricultural season and urbanization are the major problems which leads to shortage of agricultural laborers (Deshingkar and Start, 2003).

Scarcity of farm labourers is a grave concern for the farmers, who may not even hesitate to abandon farming. The acute shortage of agricultural labourers in the state has led the delay in crop establishment, poor crop growth, no or untimely weeding, irrational use of fertilizers, insufficient irrigation to crops etc. which has pressed Indian farmers to shift from farming to non-farm activities. There are evidences of shift in cropping patterns in irrigated and rainfed agriculture due to increased labour scarcity (Baba et al., 2011).

Over the past couple of decades, there is a growing concern that the farm labour had been decreasing which has been caused by occupational changes, people's mindset, Government policies and reforms making it imperative to investigate into the dynamics or scarcity of agricultural labour and its effect on agricultural economy.

Taking into consideration this pressing problems existing in agricultural economy and unmanageable situations, this study was undertaken. The causes of labour scarcity and alternative solutions being region-specific, the study would be restricted to North Karnataka, where labour scarcity is being felt as a persistent disturbance by most of the farmers. Keeping the above said facts in view, present study aims at analyzing the dynamics of labour scarcity in North Eastern Karnataka.

\section{Materials and Methods}

The study was undertaken in Raichur, Koppal and Kalaburagi districts of north eastern 
Karnataka during the year 2016-17. The sample districts were selected based on the area occupied by the prominent crops of north eastern Karnataka region viz., Cotton, Paddy and Redgram. The secondary data on area wise details across districts revealed highest area under cotton in Raichur, similarly highest area under paddy and redgram were observed in districts of Koppal and Kalaburagi respectively. Primary data collected pertained to the previous year. The stratified random sampling technique was used for the selection of respondents and agricultural labourers. Two taluks from each district and two villages from each taluk were selected for the study. The village with highest net area under cultivation was selected purposively from each taluk. The sample size was restricted to 180 farmers and 60 agricultural labourers at the rate of 15 farmers and 5 agricultural labourers from each village. The sample farmers were post-stratified crop wise, viz. paddy, redgram and cotton and were further categorized into labour scarcity- affected and non-affected farmers and labour saving technology-adopted and non-adopted farmers, respectively, for each crop to carry out the analysis.

Based on the nature and extent of data, the Student t test, Mann Whitney $\mathrm{U}$ test, and Logit model techniques were employed. The unpaired t-test and Mann Whitney U test was employed to assess the statistical significance of the difference in the mean productivity levels of labour-scarcity-affected and unaffected farms and labour-saving technology-adopted and non-adopted farms, respectively.

The following assumptions were made for classifying the labour scarcity affected and unaffected farms and labour saving technology adopted and non adopted farms.

The farms wherein there was a cumulative delay of 10 days or more in carrying out any one or more of the agricultural operations in the previous season were categorized as labour-scarcity affected farms.

The farms wherein at least one of the labor saving- technologies / implements listed in Appendix-I, if adopted, were categorized as labor saving technology-adopted farms.

\section{Results and Discussion}

The data on the productivity of the major crops which are predominantly grown in the study districts for the year 2014-15 were collected from the four villages in each of the districts of Raichur, Koppal and Kalaburagi.

\section{Productivity levels of labour saving technology adopted and non-adopted farms}

Table-1 gives the productivity levels of major crop grown in the selected districts by labour saving technology adopters and non adopters. Cotton, paddy and redgram the predominantly grown crops in Raichur, Koppal and Kalaburagi district respectively were selected for the analysis. A comparison of average productivity levels of major crop in labour saving technology adopted and non adopted farms, revealed a reduction in yield invariably in selected crops in labour saving technology non adopted farms. The productivity difference was more pronounced in paddy $(850 \mathrm{~kg} / \mathrm{ha})$, followed by cotton $(319 \mathrm{~kg} / \mathrm{ha})$ and $(224 \mathrm{~kg} / \mathrm{ha})$. The diagrammatic representation is given in Figure-1.

The average productivity levels of the labour saving technology adopted farmers and nonadopted farmers were tested for significant difference using student t-test analysis and the results revealed that the productivity levels of labour saving technology adopted and non adopted farms for the crop like cotton and redgram showed significant difference at 1 per cent level of probability and paddy showed significant difference at 5 per cent of 
level of probability (Table-2).

\section{Estimation of labour saving technology adoption of major crops production in the study area}

The Student t-test was employed to assess the statistical significance of the difference in the average productivity levels of labour-saving technology-adopted and non-adopted farms. The productivity levels of labour saving technology adopted and non adopted farms for the crop like cotton and redgram showed significant difference at 1 per cent level of probability and paddy showed significant difference at 5 per cent of level of probability. In order to examine the variables responsible for the significance difference in mean productivity of selected crops, logit model was employed and the results are represented under the following heads.

Logit analysis using SPSS 16 software package showed that, most of the coefficients were not consistent with hypothesized relationships and their tests of significance help to indicate their importance in explaining adoption decisions of the farmers. The parameter estimates for the model was evaluated at 1 and 5 per cent level of significance.

Logit estimates for the survey location of selected districts (Table-3) revealed that apart from income, access to technology and access to credit which were found not statistically significant in explaining labour saving technology adoption; education, contact with extension agents were statistically significant at 1 and 5 per cent level of probability respectively. The positive sign and significance of the extension contact variable implied that extension was an important factor that would promote farmers adoption of the labour saving technology in the study area.

The study also revealed that the main source of technology was through extension personnel. The non-availability could be attributed to non-domestic supply and nonaccessibility in terms of quantity and time. Land holding though not statistically significant had a negative correlation with adoption. This was contrast to a priori expectation and implied that an inverse relationship existed between the land holding and adoption.

Farmer's age and education (though significant) were found to be negatively and positively related to adoption behaviour respectively. These two parameters were consistent with our a priori expectation. The implication of these findings is that a younger farmer with better education had the tendency to take risk and adopt the technology.

Table.1 Effect of Labour saving technology on productivity levels in adopted and non adopted farms $(n=180)$

\begin{tabular}{|l|l|c|c|c|}
\hline SN & \multirow{2}{*}{ Crop } & \multicolumn{2}{|c|}{ Productivity } & Productivity \\
\cline { 3 - 5 } & & $\begin{array}{c}\text { Technology adopter } \\
\text { farms (Kg/ha) }\end{array}$ & $\begin{array}{c}\text { Technology non- adopted } \\
\text { farms (Kg/ha) }\end{array}$ & \\
\hline 1. & Cotton & 1500 & 1181 & $319(21.26)$ \\
\hline 2. & Paddy & 7100 & 6250 & $850(11.97)$ \\
\hline 3. & Redgram & 1050 & 826 & $224(21.33)$ \\
\hline
\end{tabular}

Note: Figures in the parentheses indicate percentage change over the technology adopted farms 
Table.2 Productivity levels in labour saving technology adopted and non adopted farms $(\mathrm{n}=180)$

\begin{tabular}{|c|l|c|c|c|}
\hline \multirow{2}{*}{ SN } & \multirow{2}{*}{ Crop } & \multicolumn{2}{|c|}{ Productivity } & \multirow{2}{*}{ t-values } \\
\cline { 3 - 5 } & & Technology adopted farms & Technology non- adopted farms & \\
\hline 1. & Cotton & 14.5 & 8 & $5.81^{* *}$ \\
\hline 2. & Paddy & 68 & 53 & $3.26^{*}$ \\
\hline 3. & Redgram & 10 & 5 & $8.6^{* *}$ \\
\hline
\end{tabular}

**Significant @ 1\% level of probability.*Significant @ 5\% level of probability

Table.3 Estimation of labour saving technology adoption of major crop production $(\mathrm{n}=180)$

\begin{tabular}{|c|c|c|c|}
\hline \multicolumn{4}{|l|}{ Paddy } \\
\hline Variable & Parameter estimate & Standard error & odds-ratio \\
\hline Intercept & -3.81 & 1.254 & -3.04 \\
\hline Age & -0.142 & 0.036 & $-3.94 * *$ \\
\hline Education & 0.435 & 8.82 & $0.05^{* *}$ \\
\hline Landholding & -0.201 & 0.624 & $-0.32 *$ \\
\hline Income & 0.812 & 0.282 & 2.88 \\
\hline Experience in farming & -0.345 & 0.132 & $-2.61 * *$ \\
\hline Contact with Extension agent & 3.779 & 1.94 & $1.95^{*}$ \\
\hline Market Distance & -2.97 & 0.427 & $-6.96 * *$ \\
\hline Access to credit & 0.321 & 1.594 & 0.20 \\
\hline Access to technology & 0.451 & 1.694 & 0.27 \\
\hline \multicolumn{4}{|l|}{ Cotton } \\
\hline Variable & Parameter estimate & Standard error & odds-ratio \\
\hline Intercept & -4.31 & 1.841 & -2.34 \\
\hline Age & -0.215 & 0.052 & -4.13 \\
\hline Education & 0.455 & 6.215 & $0.07 *$ \\
\hline Landholding & -0.351 & 0.125 & $-2.81 * *$ \\
\hline Income & 0.218 & 0.245 & 0.89 \\
\hline Experience in farming & -0.543 & 0.321 & $-1.69 *$ \\
\hline Contact with Extension agent & 4.871 & 2.102 & $2.32 * *$ \\
\hline Market Distance & -3.541 & 0.781 & $-4.53 * *$ \\
\hline Access to credit & 0.123 & 1.694 & 0.07 \\
\hline Access to technology & 0.145 & 1.875 & 0.08 \\
\hline \multicolumn{4}{|l|}{ Redgram } \\
\hline Variable & Parameter estimate & Standard error & odds-ratio \\
\hline Intercept & -4.81 & 1.553 & -3.10 \\
\hline Age & -0.241 & 0.062 & -3.89 \\
\hline Education & 0.435 & 8.541 & $0.05^{*}$ \\
\hline Landholding & -0.301 & 0.784 & -0.38 \\
\hline Income & 0.861 & 0.145 & 5.94 \\
\hline Experience in farming & -0.241 & 0.174 & $-1.39 * *$ \\
\hline Contact with Extension agent & 3.954 & 1.874 & 2.11 \\
\hline Market Distance & -3.541 & 0.148 & -23.93 \\
\hline Access to credit & 0.651 & 1.574 & 0.41 \\
\hline Access to technology & 0.741 & 1.981 & 0.37 \\
\hline
\end{tabular}

**Significant @ 1\% level of probability. * Significant @ 5\% level of probability 
Table.4 Productivity levels of labour scarcity affected and unaffected farmers $(n=180)$

\begin{tabular}{|c|l|c|c|c|}
\hline SN & Crop & \multicolumn{2}{|c|}{ Productivity } & \multicolumn{1}{|c|}{$\begin{array}{c}\text { Productivity } \\
\text { difference (Kg/ha) }\end{array}$} \\
\cline { 3 - 4 } & & $\begin{array}{c}\text { Labour scarcity } \\
\text { unaffected farmers } \\
(\mathrm{Kg} / \mathrm{ha})\end{array}$ & $\begin{array}{c}\text { Labour scarcity affected } \\
\text { farmers }(\mathrm{Kg} / \mathrm{ha})\end{array}$ & \\
\hline 1. & Cotton & 1430 & 1195 & $235(16.43)$ \\
\hline 2. & Paddy & 6912 & 6010 & $902(13.04)$ \\
\hline 3. & Redgram & 915 & 874 & $41(4.48)$ \\
\hline
\end{tabular}

Note: Figures in parentheses indicates percentage change over the labour scarcity unaffected farms

Table.5 Productivity levels in labour scarcity affected and unaffected farmers $(n=180)$

\begin{tabular}{|c|c|c|c|c|}
\hline \multirow[t]{2}{*}{ SN } & \multirow[t]{2}{*}{ Crop } & \multicolumn{2}{|c|}{ Productivity } & \multirow[t]{2}{*}{ t-values } \\
\hline & & $\begin{array}{l}\text { Labour scarcity unaffected } \\
\text { farmers }\end{array}$ & $\begin{array}{l}\text { Labour scarcity affected } \\
\text { farmers }\end{array}$ & \\
\hline 1. & Cotton & 18 & 4 & $4.21 * *$ \\
\hline 2. & Paddy & 27 & 46 & $3.41 *$ \\
\hline 3. & Redgram & 16 & 8 & $1.05^{\mathrm{NS}}$ \\
\hline
\end{tabular}

* Significant @ 1\% level of probability.** Significant @ 5\% level of probability

Appendix.I Labour-saving technologies / implements available for the selected crops

\begin{tabular}{|c|l|l|}
\hline SN & Crop & Implements \\
\hline $\mathbf{1}$ & Paddy & Transplanter \\
\hline \multirow{3}{*}{$\mathbf{2}$} & \multirow{3}{*}{ Cotton } & Harvester \\
\hline & & Conoweeder \\
\hline & & Drip irrigation \\
\hline \multirow{2}{*}{$\mathbf{3}$} & Redgram & Harvester \\
\hline & & ULD pesticides \\
\hline & & Seed cum fertilizer drill \\
\hline
\end{tabular}

Fig.1 Productivity levels of labour saving technology adopted and non adopted farms

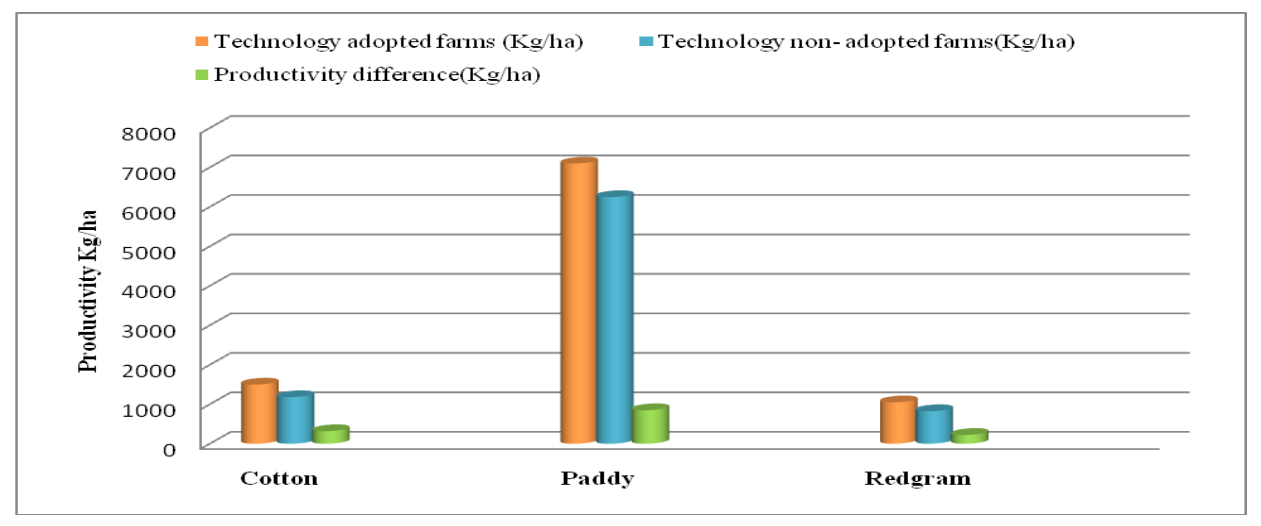


Fig.2 Productivity levels of labour scarcity affected and unaffected farms

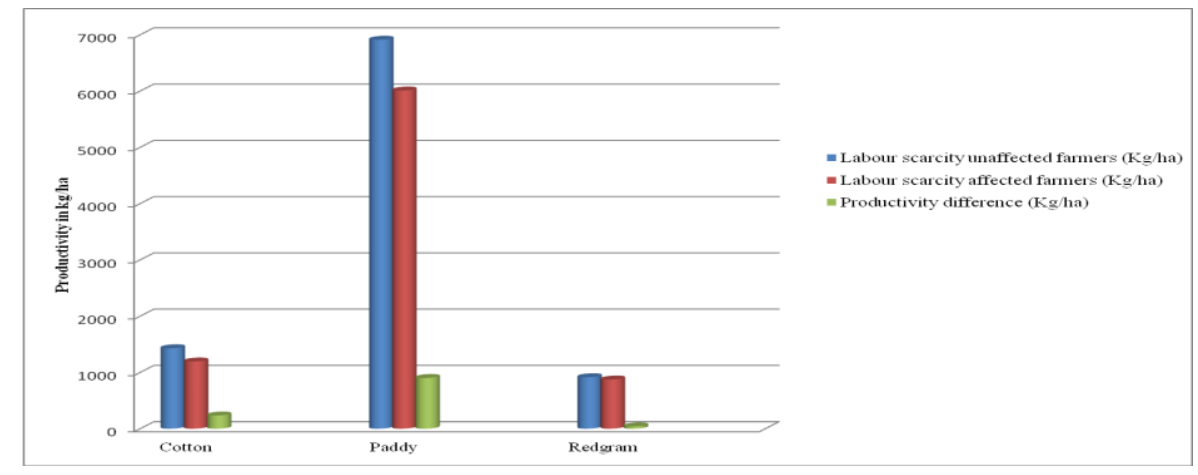

Productivity levels of labour scarcity affected and unaffected farms

A comparison of the average productivity levels of labour scarcity affected and unaffected farms of major crops grown in the study districts revealed that there was yield reduction in the selected crops in labour scarcity affected farms, in comparison with unaffected farms. The productivity difference was more pronounced in cotton crop $(16.43 \%)$, paddy (13.04) and in case of redgram it was just $(3.84 \%)$ which can be seen in Table- 4 and depicted in figure- 2 .

The unpaired t-test employed to confirm the productivity levels in two groups, viz., labour scarcity affected and unaffected farms, has revealed a significant difference statistically. The study has found a significant difference in the average productivity levels between the labour scarcity affected and unaffected farms, except for redgram, for which it was nonsignificant (Table-5).

In conclusion the productivity difference was seen for labour saving technology adopted and non adopted farmers. A comparison of average productivity levels of major crop in labour saving technology adopted and non adopted farmers, revealed a reduction in yield invariably in selected crops in labour saving technology non adopted farms. The productivity difference was more pronounced in all the selected crops. Further, a comparison of the average productivity levels of labour scarcity affected and unaffected farms of major crops grown in the study districts revealed that there was yield reduction in the selected crops in labour scarcity affected farms in comparison with unaffected farms. The highest productivity gap was observed in cotton crop followed by paddy and in case of redgram it was just per cent. Custom hiring is to be encouraged among farmers for adoption of the highly expensive labour saving technologies/ implements. Agricultural extension system of the districts has to be geared up, to bring farmers out from the conventional methods of cultivation and educate them on adoption of available labour saving implements. Proper training programmes need to be implemented for improving the skill of agricultural labours.

\section{References}

Baba, S. H., Wahi, M. H., Shaheen, F. H., Zargar, B. A. and Kubrevi, S. S. (2011). Scarcity of agricultural labour in coldarid Ladakh: extent, backward bending and coping mechanism. Agric. Econ. Res. Rev., 24(Conference): 391-400.

Deshingkar, P. and Start, D. (2003). Seasonal migration for livelihood, coping, accumulation and exclusion. Working Paper No. 220, Overseas Development Institute, London. 
Deshingkar, P. and Start, D. (2003). Seasonal migration for livelihood, coping, accumulation and exclusion. Working Paper No. 220, Overseas Development Institute, London.

Dreze, Makbul Khan and Dhar, P. K. (1992). An article of agricultural labour problems in Barpeta of Assam. Iosr Journal of Pharmacy, 3(2): 11-13. in India - A close look. Orissa Review. February-March, The Indian Journal of Labour Economics, Vol. 37, No. 1, January- March, 3-16.

Prabakar, C., Sita Devi, K. and Selvam S. (2011). Economic study of supplydemand gap of the agricultural labourers in Tamil Nadu. Agric. Econ. Res. Rev., 24: 373-380.

Padhi Kulamani, (2007). Agricultural labour

\section{How to cite this article:}

Gunabhagya and Amrutha T. Joshi. 2020. Effect of Labour Saving Technology on Crop Productivity in Northern Dry Zone of Karnataka. Int.J.Curr.Microbiol.App.Sci. 9(07): 25672574. doi: https://doi.org/10.20546/ijcmas.2020.907.302 